\title{
Correlation between mastery on the simple present tense and writing descriptive paragraph
}

\author{
Lidia Deviga $^{1}$, Yuda Fika Diliyana ${ }^{1}$ \\ ${ }^{1}$ Bhakti Husada Mulia College of Health Science of Madiun, Indonesia
}



Copyright (0) 2018 Department of English Teaching. All rights reserved.

\section{Corresponding Author:}

Lidia Deviga,

Bhakti Husada Mulia College of Health Science of Madiun

Email: devigalidya@gmail.com

\section{INTRODUCTION}

In Indonesian, English is foreign language. English is taught educational level. English is used not only to access information, but also to make interpersonal relation in daily activities. The students need good knowledge of the language components such as grammatical, structure, vocabulary and pronunciation. The students have to master grammar, so that they can produce sentences grammatically correct and easily understandable. Grammar also plays an important role in oral and written language. Consequently Everyone should master grammar if they want to be successful in learning English as foreign language. Realizing the role of the English as the international language, the students are also important to have communicative competence. Especially in writing skill because through writing, they can express their ideas to other people and the students can communication.

Writing involves several components for example grammatical structure, punctuation and capitalization. If they want to have good skill in writing, they should practice a lot in this skill. In this research, the mastery of grammar is emphasized on tenses, especially the simple present tense because it is one of the tenses that must be taught to students as the basic tense to master since it will give influence to master the other tenses. If they master the Simple Present Tense they will write easily, especially about their daily activities, general truth and description of something. The writer choose A Study on the correlation between mastery on the simple present tense and writing descriptive paragraph of the students at nursing program of STIKES Bhakti Husada Mulia Madiun Academic Year 2017/2018 "because the writer wants to 
know how good the students "mastery on the Simple Present Tense. Based on the description above, it is necessary to make a study to find out weather or not there is any correlation between the students 'mastery on the Simple Present Tense and their ability on writing descriptive text.

\section{METHOD}

This research is correlation research study to take the correlation between two different variables. There are two variables. The first is the mastery on the simple present tense, which represented by $\mathrm{X}$. The second variable is ability writing descriptive paragraph, which represented by Y. On the basic, scientific research is categorized into two; they are quantitative and qualitative research. Quantitative research is research which carried out by collecting numerical data from sample drawn from a certain population. On the other hand, qualitative research is research which collects some type of non-numerical data to answer a research question. Based on the explanation above, this study constitutes a quantitative research.

This research is quantitative research. According to Margono (2007: 105), quantitative research is a process to find knowledge which use numeral data as tool to find explanation about what we would like to know. Meanwhile, Cresswell (2007: 46) states that quantitative research is a type of educational research in which researcher decides what to study; as specific, narrow questions, collects quantifiable data from participants; analyze these numbers using statistics and conducts the inquiry in unbiased, objective manner. In this research, the researcher uses correlation design to investigate relationship between two variables. According to Cresswell (2007: 60), correlation designs are procedures in quantitative research in which investigators or more variables using the statistical procedures of correlation analysis. And Margono (2007: 106), states that correlation is a research of relationship.

From the explanation, above correlation design is procedures of quantitative research to find out relationship between two variables, i.es. correlation product moment. In this research, the researcher wants to investigate the relationship between two variables, i.e. students'mastery on present tense and writing descriptive paragraph. This research is intended to know whether or not there is correlation between present tense mastery and ability of writing descriptive paragraph of the forth semester nursing students of STIKES Bhakti Husada Mulia Madiun in academic 2017/2018, the correlation design is chosen to be the appropriate one. The procedures to be followed in conducting this research are; (a) Giving test to the class both test of present tense mastery and test on writing descriptive paragraph. (b) Analyzing the scores by using correlation product moment.

Population is the entire subject in the researcher (Arikunto, 1992 :102). If a people want to research all of elements that include in the research, so the research called population research. In line with quantitative above that population are all of individual in the research and needed to the while number of the forth semester nursing students of STIKES Bhakti Husada Mulia Madiun. The numbers of the students are 120 students are divided into forth semester. They are class A, B, and C. There are 39 students in A, 42 students in B, and 40 students in C. Arikunto (1997:104) states that sample is a group of people chosen from population through to present the population. We can call sample if we want to generalize the result of sample. Generalize it means take the research conclusion as something to all population. Because of limited time, the writer decides to take class B at the sample. The samples of this study are 42 students.

Correlation between mastery on the simple present tense and writing descriptive paragraph (Lidia Deviga) 


\section{RESULTS AND DISCUSSION}

The result from the calculation by using Pearson Product Moment Correlation, showed that for simple present tense mastery positively correlated with students ability in writing descriptive text. This is evident from the 42 students, there are 3 students (7,1\%) with score "between 44-50" (low-level), 4 students (29,5\%) with score 'between 65-71'( medium level, and 1 students (2,4\%) get high-level frequency (79-88), The total score is 2616 and the mean score of students' simple present is 67 , which was the highest score is 88 and the lowest is 44 . It means that half of the students get score over 67 and half below 67 . According to Harmer (1987: 4) grammatical mastery is very important in a language. Grammatical aspects determine the rules of sentences in the language built. Therefore, the English department program has attempted to improve students knowledge and skill in using language not only smoothly and acceptable but accurately, including accuracy in the use of grammar.

Similarly, writing ability, almost all students have the ability to write high-level understanding. The highest score gained in the writing ability test is 85 and the lowest score is 40 . The total score is 2760 . While the means score of students' writing descriptive text test is 66 . This is evident from the 42 students there are 4 students who have the ability to write high-level of understanding, and 11 students have the ability to write medium-level understanding and there are 9 students who have the ability to write low - level of understanding. It means that $21,4 \%$ had low level in writing ability, 26,2\% had medium-level in writing ability and 9,5\% had high-level in writing ability. Brown (2004: 218) states that writing is a convention of recording speech and to strengthen the language and lexical features of the language. Someone must know about grammar and text features that will help them write well. It can be concluded that the students ability to write with grammar understanding has a very strong relationship. Therefore, on the result of simple present tense mastery and writing descriptive text in the form of the aspects of writing based on the high-level and low-level of students, students who have good or high-level in mastery are good in all of aspects of writing (content, form, grammar, style, and mechanic). Whereas, students who have bad or low-level in writing ability in English get score lower than students who have good or high-level in five aspects of writing.

To prove whether or not there is a correlation between mastery on the simple present tense and their ability in writing paragraph, the writer compute using second formula of Person's Product Moment to find out the coefficient of correlation. Based on the result of research, it had shown that simple present tense mastery positively correlated with students ability in writing descriptive text. Based on the result above, it can be seen that the result was higher. Besides that, simple present tense mastery can improve each aspects of students' ability in writing descriptive text. At the beginning of activity, the test was conducted in STIKES Bhakti Husada Mulia Madiun in the academic year of 2017/2018. The test was given to 42 students of the forth semester nursing from 120 populations.the sample of the research was taken from class 4B.in collecting data, it was used objective test. The writer prepared 25 items of multiple choice question for simple present tense mastery. And used pictures as instrument for writing descriptive text test. The writing text consisted of describing a particular person, place or thing. In this case, the students descriptive text that during 60 minutes for time allocation.

To analyze the data, Product Moment used to getting the result of the simple present tense mastery and result of the writing descriptive text. After finding out the correlation cooefficient $r$ xy the 
researcher consults it to the product moment table at the significant level of $5 \%$.It was gained that the correlation coefficient is 0.756 . Whereas, $\mathrm{r}$ value of product moment table with $\mathrm{N}=42$ at the significant level of $5 \%$ is 0.304 .If the correlation coefficient rxy is higher than $r$ value of product moment table at the significant level of $5 \%$, so there is significant, and Null Hypothesis (Ho) is rejected. In the other hand, if the correlation coefficient $\mathrm{r} x \mathrm{x}$ is lower than $\mathrm{r}$ value of product moment table at the significant level of $5 \%$, so there is no significant, and Null Hypothesis is accepted. Based on the explanation above, it can be concluded that there is significant correlation between the mastery on simple present tense and the ability in writing descriptive text .It was shown that the correlation coefficient in this study (0.756) is higher than the $r$ value of significant level at $5 \%$ (0.304).Theoretically, Null Hypothesis (Ho)is rejected and Alternative Hypothesis (Ha) is accepted. By another word there is significant correlation between the students' mastery on simple present tense and their ability in writing descriptive text of the forth semester nursing students of STIKES Bhakti Husada Mulia Madiun in the academic year of 2017/2018. Having analysis the data of simple present tense test by using formula, the result shows the coefficient is 0.758.It means that there is a significant increase in writing descriptive text.

In this research, the independent variable, simple present tense mastery $(\mathrm{X})$ was highly influenced by the variable dependent variable, the ability of writing descriptive text (Y). And dependent variable, the ability of writing descriptive text $(\mathrm{Y})$ was also highly influenced by the variable Y. By seeing the result of the data calculation in the previous chapter, it was showed that the alternative hypothesis (Ha) was consequently accepted, it means that there was positive correlation between students simple present tense mastery and their ability in writing descriptive text at the forth semester nursing of STIKES Bhakti Husada Mulia Madiun in the Academic 2017/2018. In other words, the null hypothesis (Ho) was rejected and alternative hypothesis ( Ha)_ was accepted. It means that there was positive correlation between Simple Present Tense Mastery and their ability in writing descriptive text at the forth semester nursing students of STIKES Bhakti Husada Mulia Madiun in the Academic year 2017/2018. Based on this research, it was suggested that to have a good in writing descriptive text, students should have a good mastery of present tense. It was supported by the previous research that was conducted by Tarmizi about the correlation between present tense mastery and translating descriptive text amongst the eleventh grade students of SMAN 1 Seunuddon Banda Aceh. The result of the research has shown that there is positive correlation between present tense mastery and the ability of writingdescriptive text. Thus, it indicates the connection between grammar especially present tense and writing ability in descriptive text is significant.

\section{CONCLUSION}

In this study, its stated, in this research the researcher wants to find out the correlation between the students' mastery on the simple present tense and their ability in writing descriptive text. Based on the data and interpretation which is described previously, the researcher concluded as follow:

Based on the result of simple present tense, the smallest score is 44 . In the other hand, the highest score is 88 . The total of sample is 42 . From the result of writing descriptive test, in the smallest score is 40 , while the highest score is 85 from 42 samples. The researcher uses the Product Moment to find out whether there is significant correlation between the simple present tense and writing descriptive text. The result is interpreted by consulting to the product moment table. The result score of $\mathrm{r} x \mathrm{y}$ is 0.756 . Meanwhile, $\mathrm{r}$ value

Correlation between mastery on the simple present tense and writing descriptive paragraph (Lidia Deviga) 
of product moment at significant level of $5 \%$ with $\mathrm{N}=42$ IS 0.304 . It is shown that $\mathrm{r}$ xy is higher than $\mathrm{r}$ table. So, $(\mathrm{Ho})$ is rejected and $(\mathrm{Ha})$ is accepted. Thus, there is significant correlation between the students' mastery on simple present tense and their ability in writing descriptive text of the forth semester nursing students of

STIKES Bhakti Husada Mulia Madiun in the academic year of 2017/2018

\section{REFERENCES}

Arikunto, S. (2006). Prosedur Penelitian Suatu Pendekatan Praktik. Rineka Cipta: Jakarta.

Azar, B. S. (1989). Understanding and Using English Grammar Second Education. New Jersey: Engle wood Cliffs.

Brown, H.D. (2000). Principles of Language Learning and Teaching (4thed). New York: Addison Wesley Longman.

Cresswel, J. W. 2008. "Educational Research Planning Conducting and Evaluating Quantitative and Qualitative Research. "Third Edition.New Jersey: Pearson Education.

Harris, D. (1974). Testing English at The Second Language. New Delhi: Tato Mo Graw Hill, Publishing Co.Ltd.

Nunan, D. (1998). Language Teaching Methodologi: A Textbookfor Teacher. New York: Prentice Hall.

Nunan, D (Ed). (2003). Practical English Language Teaching. New York: Mc. Graw Hill.

Sugiono. (2009). Metode Penelitian Pendidikan. Bandung: Alfabeta.

Thombury, S. (2000). How to Teach gramma. Oxford: Longman.

Wiyono, E. (2008). Using Pictures to Improve the Students Achievement of Writing Recount of the Second Year Student of SMP N 1 Sunmber Gempol in the Academic Year of 2007/2008. Unpublised Thesis. 